УДК 622.23:349.6

DOI https://doi.org/10.32837/apdp.v0i83.131

А. Ю. Пльохова

\title{
ПРАВОВЕ ЗАБЕЗПЕЧЕННЯ ЕКОЛОГІЧНОЇ БЕЗПЕКИ НА ПЕРЕДПРОЕКТНІЙ СТАДІЇ ВИДОБУВАННЯ ВУГІЛЛЯ
}

Постановка проблеми. Надрокористування є одним із найважливіших видів господарської діяльності для сучасної України, якому притаманні гострі питанні екологічної безпеки. Подібне твердження має не тільки конституційне підгрунтя, згідно з яким надра відносяться до об'єктів права власності Українського народу $[1$, ст. 13], а й вагоме надроресурсне, оскільки відповідно до Закону України «Про Основні засади (стратегію) державної екологічної політики України на період до 2030 року» [2]: а) на території України, яка становить 0,4 відсотка суходолу планети, виявлено до п'яти відсотків усіх мінерально-сировинних ресурсів земної кулі; б) в Україні виявлено понад 20 тисяч родовищ і рудопроявів із 95 видів корисних копалин, із яких близько 8 тисяч родовищ мають промислове значення і обліковуються Державним балансом запасів корисних копалин.

Усвідомлюючи надзвичайно високий рівень загрози екологічній безпеці від процесів користування надрами, Кодекс України про надра (далі - КпН) визначив одним із свої завдань регулювання гірничих відносин із метою гарантування під час користування надрами безпеки людей, майна та навколишнього природного середовища (далі - НПС) [3, ст. 2]. Реалізація зазначеного завдання розкривається в багатьох приписах КпН. Наприклад, під час геологічного вивчення надр повинен забезпечуватися екологічно безпечний для життя і здоров'я людей стан НПС [3, ст. 38], із метою запобігання негативним демографічним, соціальним та екологічним наслідкам інтенсивного видобутку корисних копалин установлюються квоти на видобуток окремих видів корисних копалин [3, ст. 52] тощо.

У той же час найбільш затребуваними в Україні наразі $є$ викопні ресурси, а саме природний газ і вугілля, які сумарно становлять понад $60 \%$ вітчизняного енергетичного балансу. При цьому держава цілком усвідомлює, що зниження енергоємності економіки, а також диверсифікація джерел і шляхів постачання енергоресурсів, нарощування вітчизняного виробництва сприятимуть підвищенню економічної, енергетичної та екологічної безпеки [4].

Однією з базових галузей національної економіки є вугільна промисловість, яка в сучасних умовах тривалий час перебуває у кризовому стані. Незважаючи на вжиття певних заходів і підтримку галузі з боку держави, динаміка основних показників стану державного сектору вугільної промисловості свідчить, що криза в галузі тільки посилюється. Натомість реалізація прийнятої урядом Концепції в тому числі дасть змогу забезпечити повне, своєчасне та безперервне задоволення зростаючих потреб національної економіки якісною вітчизняною вугільною продукцією за максимального рівня промислової та екологічної безпеки [5]. У цьому зв'язку дослідження динамічних змін змісту правовідносин забезпечення екологічної безпеки на різних стадіях існування вугледобувного об'єкта є доволі значущим та актуальним.

(ㄷ) А. Ю. Пльохова, 2019 
Аналіз останніх досліджень. Слід визнати, що дослідженню проблем екологічної безпеки у сфері, що розглядається, приділено досить багато уваги і з боку екологів, і з боку гірників та геологів. Натомість серед правничих публікацій тема вугільного права взагалі та їі безпекової складової частини зокрема $є$ не дуже привабливою, що пов'язане, перш за все, зі складністю та специфікою предмету дослідження. Так, у попередній роботі здійснена спроба лише окреслити цю, як уявляється, важливу науково-практичну проблему у представницькому колі фахівців у сфері екологічних аспектів видобутку горючих копалин [6].

На думку Ю.О. Краснової, право екологічної безпеки є підгалуззю екологічного права, а природо-ресурсне право вона визнає галуззю [7, с. 4]. Така позиція є досить дискусійною, адже за теорією екологічного права право екологічної безпеки та природо-ресурсне право є складовими правовими угрупуваннями одного рівня.

Пропозиція А.С. Свстігнєєва [8, с. 17] щодо нової редакції п. 3 ч. 2 ст. 24 КпН викликає заперечення, оскільки автор аналізує такий склад користування надрами, як видобуток газу (метану) нафтових родовищ, у той час як видобуток такого виду корисної копалин врегульовано Законом України «Про газ (метан) вугільних родовищ» .

Підводячи підсумки свого дослідження, Н.А. Макаренко зазначила, що головним механізмом формування та вдосконалення законодавства з екологічної безпеки під час видобування нафти та газу має бути збалансована державна політика, спрямована на підвищення вимог і відповідальності суб'єктів господарювання за забруднення НПС і на стимулювання впровадження природоохоронних заходів [9, с. 134]. Вона ж захищає положення про міжгалузевий характер системи правових норм у сфері регулювання екологічної безпеки під час видобування нафти й газу, яка включає: а) правові норми щодо використання природних ресурсів та охорони НПС, у тому числі правові норми у сфері видобування нафти та газу (природо-ресурсний та природоохоронний характер); б) правові норми щодо регулювання екологічної безпеки в галузі промисловості, в тому числі правові норми у сфері регулювання екологічної безпеки під час видобування нафти й газу (антропоохоронний характер); дослідниця запропонувала вважати таку систему правових норм комплексним міжгалузевим інститутом екологічного права [10, с. 5].

Огляд та аналіз правових засада забезпечення екологічної безпеки під час здійснення таких видів господарської діяльності, як гірничодобувна та переробна, а також детальне співставлення прав і обов'язків суб'єктів у ланці «надрокористування - контроль та нагляд - відповідальність» із обґрунтуванням висновку про їх недостатню кореляцію виконав Р.С. Кірін [11; 12].

І.Д. Багрій, досліджуючи екологічні проблеми видобутку шахтного метану, вказує на те, що розвиток вугільної промисловості України знаходиться нині у прямій залежності від успішного вирішення питань дегазації вугільних пластів та боротьби з газодинамічними явищами (далі - ГДЯ). При цьому він виділяє: 1) види ускладнень гірничо-геологічних умов: зниження стійкості виробок, зміни напружено-деформованого стану гірського масиву, збільшення газоносності та викидонебезпеки; 2) види ГДЯ: раптові викиди вугілля, породи й газу; гірничі удари, раптові обвалення, прориви газу, видавлення вугілля [13]. 
Слід погодитися з думкою зазначеного автора відносно того, що ГДЯ є причиною аварій на шахтах та людських жертв. Під час переходу на більш глибокі горизонти газовий режим гірничих виробок (виділення в них метану та інших газів) стає основним чинником, який суттєво впливає на умови безпеки й стримує темпи гірничо-видобувних робіт. Окрім цього, виділення метану в повітря викликає значне погіршення екологічного стану довкілля, перш за все забруднення атмосферного повітря та підсилення парникового ефекту, оскільки: а) у структурі викидів парникових газів в Україні метан займає близько $35 \%$; б) викиди метану в процесі видобутку вугілля складають $80 \%$ від усіх викидів метану в енергетиці України; в) основними джерелами викидів метану з вугільних родовищ є системи вентиляції та дегазації [13].

Автори статті[14]вказують на такі першочергові завдання права екологічної безпеки під час видобування сланцевого газу, як: 1) ліквідація прогалин та невідповідностей у законах, що регулюють розвідку нафти і газу та експлуатаційну діяльність в Україні; 2) вдосконалення законодавства у частині: 2.1) вилучення земельних ділянок для розроблення родовищ вуглеводнів із метою максимального забезпечення прав та інтересів їх власників і користувачів; 2.2) забезпечення належних страхових відшкодувань юридичним та фізичним особам за екологічні ризики, пов'язані з геологічним вивченням та промисловим розробленням газових родовищ. Ухвалення управлінських рішень про доцільність видобування сланцевого газу має відбуватися паралельно з формуванням екологічних критеріїв його видобування та за належної, докладної та відкритої оцінки впливу таких проектів на НПС [14].

Отже, можна констатувати, що проблема забезпечення екологічної безпеки у процесі видобування корисних копалин (далі - ВКК) була і залишається достатньо актуальною, про що свідчать напрацювання не тільки представників правничої сфери, але й науковців гірничої справи та екології. Проте питання, пов’язані з дослідженням зміни еко-безпекових прав і обов'язків відповідних суб'єктів на різних стадіях підготовки, здійснення та припинення видобування вугілля, залишаються актуальними.

Тож метою статті визначено виявлення особливостей змісту правовідносин із забезпечення екологічної безпеки на передпроектній стадії видобування вугілля.

Виклад основного матеріалу. Дослідження напряму, зазначеного в темі цієї роботи, буде спиратися на два загальнотеоретичні, засадничі у юридичній науці положення, а саме: 1) конкретна поведінка суб’єктів правовідносин та їі юридичне закріплення нормами права у вигляді сукупності суб'єктивних прав та юридичних обов’язків розглядається як зміст правовідносин; 2) конкретні життєві обставини, з якими норми права пов'язують правові наслідки, розглядаються як необхідні підстави динаміки правовідносин між суб’єктами - виникнення, зміни і припинення.

Основним законодавчим актом, що безпосередньо регулює відносини екологічної безпеки під час видобування вугілля, вважається Гірничий закон України [15], в розділі VI «Особливості екологічної безпеки гірничих робіт» якого встановлені: 1) основні екологічні вимоги у сфері проведення гірничих робіт [15, ст. 34]; 2) запобігання шкідливому впливу гірничих робіт [15, ст. 35]; 3) заходи щодо забезпечення екологічної безпеки під час проведення гірничих робіт [15, ст. 36]. 
Аналіз нормативно-правових актів гірничого та надрового законодавства дав підстави стверджувати, що однією з особливостей правового забезпечення екологічної безпеки під час видобування вугілля є специфіка кожної зі стадії існування вугледобувного підприємства у часі зі специфічним змістом відповідної сукупності правовідносин.

Розташування гірничих підприєлств [15, ст. 12]. Місця розташування гірничих підприємств визначаються до початку проектних робіт цих підприємств. Відведення землі під розташування гірничого підприємства проводиться в порядку, встановленому Земельним кодексом України (далі - ЗК), а надання гірничого відводу - КпН. Зокрема, під час надання гірничих відводів вирішуються питання щодо:

1) правильності поділу родовищ корисних копалин (далі - РКК) на окремі гірничі відводи з метою запобігання залишенню поза гірничими відводами менш цінних ділянок РКК та не придатних для самостійної розробки;

2) дотримання вимог безпеки під час проведення гірничих і підривних робіт під час розроблення РКК та під час використання надр для інших цілей, не пов'язаних iз BKK;

3) відвернення небезпеки для людей, майна та НПС [3, ст. 17].

До квітня 2014 р. ст. 49 КпН передбачала погодження місць розташування гірничодобувних об'єктів і підземних споруд, не пов'язаних із ВКК, у тому числі для підземного зберігання нафти, газу та інших речовин і матеріалів, захоронення відходів виробництва, інших шкідливих речовин і скидання стічних вод, до початку проектних робіт, але на підставі закону від 09.04.2014 p. [16] ця стаття з КпН була виключена. На підставі цього ж закону були виключені п.п. 103, 104 (відповідно, «Погодження місць розташування гірничодобувних об’єктів і підземних споруд, не пов'язаних із ВКК, у тому числі для підземного зберігання нафти, газу та інших речовин і матеріалів, захоронення відходів виробництва, інших шкідливих речовин і скидання стічних вод до початку проектних робіт» та «Погодження місць розташування гірничих підприємств на підпорядкованій їм території виходячи з інтересів територіальної громади») з Переліку документів дозвільного характеру у сфері господарської діяльності [17].

Зелельна ділянка. Надання земельних ділянок для потреб, пов'язаних із користуванням надрами, згідно із ст. 66 ЗК проводиться після оформлення в установленому порядку прав користування надрами і відновлення земель згідно із затвердженим відповідним робочим проектом землеустрою на раніше відпрацьованих площах у встановлені строки. Землі, надані для розміщення та експлуатації основних, підсобних і допоміжних будівель та споруд гірничодобувних підприємств, їх під’їних шляхів, інженерних мереж, адміністративно-побутових будівель, інших споруд, належать до земель промисловості, які можуть перебувати в державній, комунальній та приватній власності. Розміри земельних ділянок, що надаються для зазначених цілей, визначаються відповідно до затверджених в установленому порядку державних норм і проектної документації, а відведення земельних ділянок здійснюється з урахуванням черговості їх освоєння.

У свою чергу, у ст. 16 КпН встановлено, що надання спеціальних дозволів на користування надрами (далі - спецдозвіл), крім випадків користування надрами 
на умовах угод про розподіл продукції, укладених відповідно до Закону України «Про угоди про розподіл продукції», здійснюється після попереднього погодження з відповідною радою питання про надання земельної ділянки для зазначених потреб, крім випадків, коли в наданні земельної ділянки немає потреби.

Отже, виходячи із цих приписів земельного та надрового законодавства, наявним є механізм, відповідно до якого: а) надання земельних ділянок для потреб, пов'язаних із користуванням надрами, проводиться після оформлення в установленому порядку прав користування надрами; б) надання спецдозволів здійснюється після попереднього погодження з відповідною радою питання про надання земельної ділянки для зазначених потреб. Тобто в даному випадку потребують пояснення поняття «оформлення прав користування надрами» та «погодження надання земельної ділянки», оскільки подібні законодавчі формулювання можуть бути підставою для висновку, згідно з яким надання земельної ділянки для користуванням надрами можливе лише за наявності спецдозволу, який надається після надання земельної ділянки.

Розірвати уявне «замкнуте коло» допоможе лише прискіпливий аналіз кодифікованих актів КпН та ЗК. По-перше, виходячи з положень ст. 18 КпН, маємо: 1) надра надаються в користування відповідним суб'єктам лише за наявності в них спецдозволу; 2) право на користування надрами засвідчується актом про надання гірничого відводу; 3) земельні ділянки для користування надрами надаються користувачам надр після одержання ними спецдозволів чи гірничих відводів. У свою чергу, останні можуть надаватися суб'єктам лише за наявності в них спецдозволу, а також затвердженого в установленому порядку проекту розроблення РКК або будівництва гірничодобувного об'єкта [20]. Тож очевидно, що етап надання гірничого відводу не відноситься до передпроектної стадії видобування вугілля, хоча при цьому зумовлює певний об'єктний склад відносин із забезпечення екологічної безпеки.

По-друге, ключовим терміном під час надання земельної ділянки для користування ділянкою надр є вимога «попереднього погодження з відповідною радою» . У цьому аспекті слід враховувати такі приписи ЗК: 1) порядок надання земельних ділянок державної або комунальної власності в користування встановлено ст. $123 ; 2$ ) особа, зацікавлена в одержанні в користування земельної ділянки із земель державної або комунальної власності за проектом землеустрою щодо їі відведення, звертається з клопотанням про надання дозволу на його розроблення до уповноваженого органу (ст. 123-2); 3) у клопотанні зазначаються орієнтовний розмір земельної ділянки та ії цільове призначення; до клопотання додаються графічні матеріали, на яких зазначено бажане місце розташування та розмір земельної ділянки, письмова згода землекористувача, засвідчена нотаріально (у разі вилучення земельної ділянки); 4) підставою відмови в наданні такого дозволу може бути лише невідповідність місця розташування земельної ділянки вимогам законів, прийнятих відповідно до них нормативно-правових актів; 5) не підлягають продажу на конкурентних засадах (земельних торгах) земельні ділянки державної чи комунальної власності або права на них у разі використання земельних ділянок для потреб, пов'язаних із користуванням надрами відпо- 
відно до отриманих дозволів (ст. 134-2); 6) порядок погодження питань, пов’язаних із викупом земельних ділянок для суспільних потреб або з мотивів суспільної необхідності, встановлено ст. 151.

Гірничий відвід. Окрім згаданий законодавчих приписів, на підзаконному рівні також наявні положення, на які слід звернути увагу під час дослідження змісту правовідносин екологічної безпеки під час розроблення РКК на передпроектній стадії видобування вугілля. Зокрема, Звіт з оцінки впливу на довкілля (додаток до Порядку передачі документації для надання висновку з оцінки впливу на довкілля та фінансування оцінки впливу на довкілля) в тому числі включає опис місця провадження планованої діяльності (додаються: а) викопіювання з генерального плану, зонінгу або детального плану території та ситуаційна схема з нанесеними джерелами впливу на довкілля; б) відомості за підписом суб'єкта господарювання про наявність власних або орендованих виробничих площ (приміщень), необхідних для провадження господарської діяльності, разом із копіями документів, що підтверджують право власності або оренди на виробничі площі (приміщення) [18]. Відносно гірничодобувного об'єкта слід представити ситуаційну схему з нанесенням реальної ситуації в районі розміщення ділянки РКК в радіусі 2 км, а саме: позначити місце розташування підприємства (планові межі площі РКК, земельної ділянки та гірничого відводу) з відповідним відображенням даної інформації на топографічній основі із зазначенням масштабу.

Подібна інформація зазначається у спецдозволі (відомості про ділянку надр, що надається в користування), де зазначаються: її назва, місцезнаходження, координати, площа та в разі потреби обмеження щодо глибини використання [19].

Крім того, слід враховувати, що проект гірничого відводу, який додається до заявки згідно з п. 23 Положення [20], складається з пояснювальної записки та графічних матеріалів. У пояснювальній записці повинні бути викладені загальні відомості про територію, на якій знаходиться гірничий відвід, у тому числі про: 1) її географічне та адміністративне положення; 2) площу; 3) характеристику сільськогосподарських та інших угідь, річок, озер та інших водних об'єктів; 4) окремі будівлі і споруди; 5) категорії, до яких належать землі відповідно до земельного законодавства.

На копії топографічного плану поверхні зображуються рельєф поверхні і пункти опорної геодезичної сітки, контури лісових і сільськогосподарських угідь, межі землекористування і населених пунктів, гірничі виробки, водні об'єкти, будівлі і споруди, дороги, наземні та підземні комунікації, об'єкти природно-заповідного фонду, пам'ятки історії і культури та мистецтва, межі залягання РКК та суміжних гірничих відводів, а також межі проектного відводу. При цьому на підприємства і громадян, яким надано гірничий відвід, покладається обов'язок забезпечувати безпеку людей, майна, будівель, споруд та НПС.

Отже, передпроектна стадія, виходячи з положень ст. $48 \mathrm{~K} \mathrm{H}$, закінчується після попереднього погодження у встановленому законодавством порядку питань про надання земельної ділянки і гірничого відводу, коли і розпочинається проектування гірничодобувних об'єктів. Слід також враховувати, що розвідані РКК (ділянки) вважаються підготовленими до промислового освоєння, якщо [21, п. 23] в тому 
числі одержано попередні погодження на спеціальне користування земельними ділянками з метою ВКК згідно із законодавством.

Нарешті, необхідно відмітити новелу гірничого законодавства, відповідно до якої принципово змінився характер погодження надання гірничого відводу Так, згідно з постановою Кабінету Міністрів України від 12 червня 2019 р. № 500 [22] з урахуванням мети використання надр до проекту гірничого відводу додається, серед іншого, лист від органів місцевого самоврядування або органів виконавчої влади щодо отримання ними інформації про межі гірничого відводу для використання надр на території їх діяльності. До внесення зазначених змін порядок передбачав подання документу про згоду землевласника або землекористувача з рішенням про надання гірничого відводу.

Спеидозвіл. Окрім вищенаведених характеристик спецдозволу, що мають загальні риси, слід мати на увазі й його спеціальний режим, притаманний лише суб’єктам видобування вугілля [3, ст. 16].

Це, зокрема, такі: 1) надання спецдозволів суб'єкту господарювання, який отримав цілісний майновий комплекс (далі - ЦМК) державного вугледобувного підприємства в оренду чи концесію, здійснюється шляхом переоформлення спецдозволів, виданих вугледобувному підприємству державного сектору економіки, ЦМК якого передано в оренду чи концесію, на ім'я суб'єкта господарювання, який отримав ЦМК такого вугледобувного підприємства в оренду чи концесію, на строк дії такого спецдозволу та без проведення конкурсу (аукціону); 2) під час оренди чи концесії ЦМК державного вугледобувного підприємства на період отримання орендарем чи концесіонером спецдозволу та гірничого відводу орендар чи концесіонер здійснює видобуток вугілля та (або) лігніту (бурого вугілля) на об’єкті, переданому в оренду чи концесію, на підставі чинного спецдозволу та гірничого відводу державного вугледобувного підприємства, ЦМК якого передано в оренду чи концесію, але не більше 12 місяців із дня укладення договору оренди чи концесії; 3) надання спецдозволів суб’єкту господарювання, який приватизував державне вугледобувне підприємство відповідно до Закону України «Про особливості приватизації вугледобувних підприємств», здійснюється шляхом переоформлення спецдозволів, наданих зазначеному вугледобувному підприємству, на ім'я суб'єкта господарювання, який його приватизував, на строк дії такого спецдозволу та без проведення аукціону.

Таким чином, проведений аналіз наукових доробків, приписів надрового, гірничого та земельного законодавства, які розкривають особливості правового забезпечення екологічної безпеки на передпроектній стадії видобування вугілля, дав можливість сформулювати такі висновки.

1. Передпроектна стадія видобування вугілля з притаманними їй особливостями забезпечення екологічної безпеки починаються на етапі визначення місця розташування відповідних гірничих підприємств до початку проектних робіт цих підприємств. Відведення землі під розташування гірничого підприємства проводиться в порядку, встановленому ЗК: 1.1) надання земельних ділянок для потреб, пов'язаних із користуванням надрами, проводиться після оформлення в установленому порядку прав користування надрами; надання гірничого відводу - КпН: 
1.2) надання спецдозволу здійснюється після попереднього погодження з відповідною радою питання про надання земельної ділянки.

2. Земельні ділянки для користування надрами надаються користувачам надр після одержання ними спецдозволів чи гірничих відводів. Останні можуть надаватися суб'єктам лише за наявності в них спецдозволу, а також затвердженого в установленому порядку проекту розробки РКК або будівництва гірничодобувного об'єкта, тому етап надання гірничого відводу не відноситься до передпроектної стадії видобування вугілля, хоча при цьому зумовлює певний об'єктний склад відносин із забезпечення екологічної безпеки.

3. Передпроектна стадія закінчується після попереднього погодження у встановленому законодавством порядку питань про надання земельної ділянки і гірничого відводу, коли і розпочинається проектування гірничодобувних об'єктів, а розвідані РКК (ділянки) вважаються підготовленими до промислового освоєння, якщо одержано попередні погодження на спеціальне користування земельними ділянками з метою ВКК згідно із законодавством.

4. Основними новелами передпроектної стадії видобування вугілля $€: 4.1)$ скасування вимоги КпН (ст. 49) щодо погодження місць розташування гірничодобувних об’єктів і підземних споруд, не пов'язаних із ВКК; 4.2) вилучення з Переліку документів дозвільного характеру у сфері господарської діяльності вимог про погодження місць розташування гірничих підприємств та гірничих об'єктів на підпорядкованій територіальній громаді території; 4.3) перехід від погоджувального порядку надання гірничого відводу (документ про згоду землевласника або землекористувача) до повідомчого, що передбачає отримання листа від органів місцевого самоврядування або органів виконавчої влади щодо отримання ними інформації про межі гірничого відводу для використання надр на території їх діяльності.

5. До кола об’єктів відносин з екологічної безпеки на передпроектній стадії слід віднести такі їх групи: 5.1) антропоресурсні - життя і здоров’я людей, що знаходяться в активній чи/та пасивній формах участі в зоні видобування вугілля та території її впливу; 5.2) природоресурсні - довкілля, земельна ділянка для розташування вугледобувного підприємства, вугільне родовище, гірничий відвід, рельєф поверхні, лісові та сільськогосподарські угіддя, річки, озера та інші водні об'єкти, об'єкти природно-заповідного фонду; 5.3) господарсько-ресурсні - основні, підсобні та допоміжні будівлі та споруди гірничодобувних підприємств, їхні під'їзні шляхи, інженерні мережі, адміністративно-побутові будівлі, інші споруди, наземні та підземні комунікації; 5.4) історико-культурні - пам’ятки історії і культури та мистецтва.

\section{Jimepamypa}

1. Конституція України від 28 червня 1996 p. URL : https://zakon.rada.gov.ua/laws/show/254\% D0 $\%$ BA $/ 96 \%$ D0 $\%$ B2 $\%$ D1 $\% 80$ ?find $=1$ \& text.

2. «Про Основні засади (стратегію) державної екологічної політики України на період до 2030 року» : Закон України від 28 лютого 2019 року № 2697-VIII. Офіщійний вісник України від 12.04.2019 p. 2019. № 28. С. 29. Ст. 980.

3. Кодекс України про надра від 27 липня 1994 р. № 132/94-BP. URL : https://zakon.rada.gov.ua/ laws/show $/ 132 / 94-\%$ D0 $\%$ B2 $\%$ D1 $\%$ 80?find=1\&text. 
4. «Про схвалення Енергетичної стратегії України на період до 2035 року «Безпека, енергоефективність, конкурентоспроможність» : розпорядження Кабінету Міністрів України від 18 серпня 2017 р. № 605-р. Урядовий кур’єр від 08.09.2017 р. № 167.

5. «Про схвалення Концепції реформування та розвитку вугільної промисловості на період до 2020 року» : розпорядження Кабінету Міністрів України від 24 травня 2017 р. № 733-р. Офіuійний вісник України від 03.11.2017 р. 2017. № 86. С. 59. Ст. 2621.

6. Пльохова А.Ю. Стадії забезпечення екологічної безпеки під час видобування вугілля: правові аспекти. Геологія горючих копалин: досягнення та перспективи : матеріали Міжнародної науково-практичної конферениї (м. Київ, 2-5 вересня 2019 р.). Київ : Інститут геологічних наук НАН України, 2019. 168 с. С. 158-163.

7. Краснова Ю.О. Право екологічної безпеки в Україні : автореф. дис... докт. юрид. наук : 12.00.06 / НАН України; Інститут економіко-правових досліджень. Київ, 2018. $31 \mathrm{c.}$

8. Євстігнєєв А.С. Проблеми правового забезпечення екологічної безпеки у сфері спеціального природокористування в Україні : автореф. дис. ... докт. юрид. наук : 12.00 .06 / НАН України; Інститут держави і права ім. В.М. Корецького. Київ, 2019. 32 с.

9. Макаренко Н.А. Проблеми формування законодавства з питань екологічної безпеки під час видобування нафти та газу в Україні. Науковий вісник Міжнародного гуманітарного університету. Сер.: Юриспрудениіл. 2013 № 6-1 том 2. С. 131-134.

10. Макаренко Н.А. Правове регулювання екологічної безпеки в сфері видобування нафти і газу в Україні : автореф. дис... канд. юрид. наук : 12.00.06 ; Київський національний університет імені Тараса Шевченка. Київ, 2015. 18 с.

11. Кірін Р.С. Правові засади забезпечення екологічної безпеки в гірничодобувній та переробній промисловості. Проблеми права екологічної безпеки : навч. посіб. / М.В. Краснова, Г.І. Балюк, А.Г. Бобкова [та ін.] ; під заг. ред. М.В. Краснової та Р.С. Кіріна ; відп. ред. В.І. Андрейцев; М-во освіти і науки України ; Київ. нац. ун-т, Нац. гірн. ун-т. Дніпро : НГУ, 2016. 621 с. С. 294-330.

12. R. Kirin. (2019). Statutory and regulatory requirements in the process of mineral mining in Ukraine. Review and analysis. Mining of Mineral Deposits. 13(2). C. 59-65.

13. Багрій I.Д. Екологічні проблеми видобутку шахтного метану. URL : http://shalegas.in.ua/ ekologichni-problemy-vydobutku-shahtnogo-metanu/.

14. Римар М.В., Краєвська А.С., Дулин I.С. Екологічна безпека видобування сланцевого газу в Україні. Регіональна економіка. 2012. № 4. С. 109-114.

15. Гірничий закон України від 6 жовтня 1999 р. № 1127-XIV. URL : https://zakon.rada.gov.ua/ laws/show/1127-14.

16. «Про внесення змін до деяких законодавчих актів України щодо скорочення кількості документів дозвільного характеру» : Закон України від 9 квітня 2014 р. № 1193-VII. Офіційний вісник України від 08.05.2014 - 2014 р. № 36. С. 7. Ст. 954.

17. «Про Перелік документів дозвільного характеру у сфері господарської діяльності» : Закон України від 19 травня 2011 р. № 3392-VI. URL : https://zakon.rada.gov.ua/laws/show/3392-17.

18. «Про затвердження Порядку передачі документації для надання висновку з оцінки впливу на довкілля та фінансування оцінки впливу на довкілля та Порядку ведення Єдиного реєстру з оцінки впливу на довкілля» : постанова Кабінету Міністрів України від 13 грудня 2017 р. № 1026. Oфiuіŭний вісник України від 05.01.2018. 2018 р. № 2. С. 212. Ст. 58.

19. «Про затвердження Порядку надання спеціальних дозволів на користування надрами» : постанова Кабінету Міністрів України від 30 травня 2011 р. № 615. URL : https://zakon.rada.gov.ua/laws/ show $/ 615-2011-\%$ D0\% BF?find=1\&text.

20. «Про затвердження Положення про порядок надання гірничих відводів» : постанова Кабінету Міністрів України від 27 січня 1995 р. № 59. URL : https://zakon.rada.gov.ua/laws/show/ $59-95-\%$ D0 \% BF?find=1\&text.

21. «Про затвердження Класифікації запасів і ресурсів корисних копалин державного фонду надр» : постанова Кабінету Міністрів України від 5 травня 1997 р. № 432. URL : https://zakon.rada.gov.ua/ laws/show/432-97-\% D0\% BF?find=1\&text.

22. «Про внесення змін до Положення про порядок надання гірничих відводів» : постанова Кабінету Міністрів України від 12 червня 2019 р. № 500. Офіційний вісник України від 02.07.2019. № 50. С. 50. Ст. 1695 . 


\begin{abstract}
Анотація
Пльохова А. Ю. Правове забезпечення екологічної безпеки на передпроектній стадії видобування вугілля. - Стаття.

Проведено аналіз результатів наукових досліджень та положень надрового, гірничого і земельного законодавства у сфері забезпечення екологічної безпеки під час видобування вугілля. Досліджено специфіку правового забезпечення екологічної безпеки передпроектної стадії, яка розпочинається на етапі визначення місця розташування вугледобувних підприємств до початку проектних робіт цих підприємств.

Встановлено, що надання земельних ділянок для потреб, пов'язаних із користуванням надрами, проводиться після оформлення в установленому порядку прав користування надрами, а надання спецдозволу здійснюється після попереднього погодження з відповідною радою питання про надання земельної ділянки. ОбГрунтовано, що передпроектна стадія закінчується після попереднього погодження у встановленому законодавством порядку питань про надання земельної ділянки і гірничого відводу, коли й розпочинається проектування гірничодобувних об'єктів, при цьому етап надання гірничого відводу не відноситься до передпроектної стадії видобування вугілля, хоча і зумовлює певний об’єктний склад відносин екологічної безпеки.

Розкрито основні новели передпроектної стадії видобування вугілля: 1) скасування вимоги Кодексу України про надра (ст. 49) щодо погодження місць розташування гірничодобувних об'єктів; 2) вилучення з Переліку документів дозвільного характеру у сфері господарської діяльності вимог про погодження місць розташування гірничих підприємств та гірничих об'єктів на підпорядкованій територіальній громаді території; 3) перехід від погоджувального порядку надання гірничого відводу (документ про згоду землевласника або землекористувача) до повідомчого, що передбачає отримання листа від органів місцевого самоврядування або органів виконавчої влади щодо отримання ними інформації про межі гірничого відводу для використання надр на території їхньої діяльності.

Запропоновано віднести до кола об'єктів відносин з екологічної безпеки на передпроектній стадії видобування вугілля такі групи: 1) антропоресурсні - життя і здоров'я людей, що знаходяться в активній чи/та пасивній формах участі в зоні видобування вугілля та території її впливу; 2) природо-ресурсні - довкілля, земельна ділянка для розташування вугледобувного підприємства, вугільне родовище, гірничий відвід, рельєф поверхні, лісові та сільськогосподарські угіддя, річки, озера та інші водні об'єкти, об'єкти природно-заповідного фонду; 3) господарсько-ресурсні - основні, підсобні та допоміжні будівлі та споруди гірничодобувних підприємств, їхні під’їзні шляхи, інженерні мережі, адміністративно-побутові будівлі, інші споруди, наземні та підземні комунікації; 4) історико-культурні - пам'ятки історії і культури та мистецтва.
\end{abstract}

Ключові слова: розташування гірничих підприємств, земельна ділянка, гірничий відвід, вугледобувний об’єкт, спеціальний дозвіл на користування надрами.

\title{
Summary
}

Plokhova A. Yu. Legal support of environmental safety at the pre-project stage of coal mining. Article.

The results of scientific researches and the provisions of the subsoil, mining and land legislation in the field of environmental safety in coal mining have been analyzed. The legal security specifics of the pre-project stage environmental safety, which begins at the coal-mining enterprises location determining stage before these enterprises project works start.

It is established that the land plots provision for the needs related to the subsoil use is carried out after the subsoil use rights registration in the established order, and the special permit granting is carried out after prior land plot provision issue agreement with the relevant council. It is substantiated that the pre-project stage ends after preliminary agreement in the order established by the legislation on the land plot and mining allotment provision, when the mining facilities design begins, while the mining allotment granting stage does not belong to the coal mining pre-project stage, although it determines some of the objective elements of environmental security relations.

The main innovations of the coal mining pre-project stage are disclosed: 1 ) cancellation of the requirement of the Code of Ukraine on subsoil (Article 49) regarding the mining facilities locations approval; 2) withdrawal from the List of documents of the permitting nature in the economic activity sphere of the requirements for the locations approval of the mining enterprises and mining objects in the territorial subordinate territory community; 3) transition from the conciliation procedure for a mining allotment granting (document of consent of the landowner or land user) to the notification one, which provides for a letter receiving from local self-government bodies or executive bodies regarding receiving information about the mining allotment limits for the subsoil use in their territory of activity.

It is proposed to include the following groups into the range of objects of environmental safety relations at the coal mining pre-project stage: 1 ) anthroporesources - the lives and health of people who are in active 
or/and passive forms of participation in the coal extraction area and its impact area; 2) natural resources - environment, land plot for the coal mining enterprise location, coal deposit, mining allotment, surface relief, forest and agricultural land, rivers, lakes and other water objects, nature reserve fund objects; 3) economic resources - the main, ancillary and auxiliary buildings and structures of mining enterprises, their access roads, engineering networks, administrative and household buildings, other structures, terrestrial and underground communications; 4) historical and cultural - monuments of history and culture and art.

Key words: coal mining enterprise location, land plot, mining allotment, coal extraction area, special permit for the subsoil use. 